\title{
Effectiveness of interprofessional manikin-based simulation training on teamwork among real teams during trauma resuscitation in adult emergency departments: A systematic review
}

\section{Corresponding author:}

Alexandra LAPIERRE

RN, MSc, Faculty of Nursing, Université de Montréal, Montréal, Canada

2375 Chemin de la Côte-Sainte-Catherine, Montréal, QC H3T 1A8, Tel: 1-514-963-0877

Email: alexandra.lapierre@umontreal.ca

\section{Co-authors:}

\section{Sabrina BOUFERGUENE,}

BSc, Faculty of Medicine, Université de Montréal, Montréal QC, Canada

\author{
Jérome GAUVIN-LEPAGE \\ $\mathrm{RN}, \mathrm{PhD}$, Faculty of Nursing, Université de Montréal, Montréal QC, Canada \\ Research Centre, Sainte-Justine Hospital, Montréal QC, Canada
}

\section{Patrick LAVOIE}

$\mathrm{RN}, \mathrm{PhD}$, Faculty of Nursing, Université de Montréal, Montréal QC, Canada

Research center, Montreal Heart Institute, Montréal QC, Canada

\section{Caroline ARBOUR}

RN, PhD, Faculty of Nursing, Université de Montréal, Montréal QC, Canada

Research center, Sacré-Cœur Hospital, Montréal QC, Canada

\section{Declaration of interest}

The authors declare no conflicts of interest in relation to this work.

This is the final version of the manuscript accepted for publication in Simulation in Healthcare. The published version is accessible here: https://doi.org/10.1097/sih.0000000000000443 


\section{SUMMARY STATEMENT}

This systematic review synthesizes the relevant evidence about the effectiveness of interprofessional manikin-based simulation training on teamwork among real teams during trauma resuscitation in adult civilian emergency departments. A systematic literature search was conducted in MEDLINE, CINAHL, EMBASE, EBM reviews, PsycINFO, and Web of Science with no time limit. Only experimental and quasi-experimental studies were included. Effects of the simulation intervention on teamwork were categorized according a modified version of the Kirkpatrick's model. From the 1120 studies found, 11 studies were included for synthesis. All studies showed immediate improvement in teamwork after training, but divergent results were found regarding skills retention. Although this review focused on interprofessional manikin-based simulations in real trauma teams, the results are similar to previous systematic reviews including different types of simulation. This raises significant questions regarding the importance of simulation design characteristics to improve teamwork in trauma care.

Keywords: high-fidelity simulation, teamwork, traumatology, emergency service, review 


\section{INTRODUCTION}

Quality and safety in healthcare depend on the successful interaction between multiple professionals and on processes aimed at making the right resources available at the right time and place for the right patient (e.g., medications, medical equipment, information, and individuals) ${ }^{1,2}$. This is particularly true during trauma resuscitation in adult civilian emergency departments. In this phase of the trauma care trajectory, interprofessional teams must make a great number of management decisions in a short time to resuscitate, stabilize, and prepare transport of the patient to the site of definitive care ${ }^{3}$. Interprofessional trauma teams are composed of professionals from more than one discipline and typically include doctors (e.g., physicians, surgeons, residents), nurses, respiratory therapists, as well as other allied health workers ${ }^{4}$.

Most preventable errors contributing to trauma mortality and poor outcomes occur during the resuscitation phase of trauma care ${ }^{5}$. Factors contributing to these errors include time pressure, multitasking, and-most importantly-failures in teamwork performance ${ }^{5,6}$. Several issues and pitfalls in trauma teamwork performance have been observed, including reluctance to question or challenge decisions made by senior colleagues, poor communication among team members, failure to establish clear roles or goals, and failure of members to effectively function as part of a team ${ }^{4,7}$. Nevertheless, it is generally recognized that interprofessional teamwork has the potential to improve trauma care because it involves multiple professionals with greater amount and variety of knowledge to apply in decision making, problem solving, and idea generation. Furthermore, we know that professionals from multiple disciplines working in teams can accomplish tasks more effectively and efficiently than any individual or discipline working alone ${ }^{8}$.

Considering that trauma patients are particularly vulnerable to errors, it is essential that individual professionals learn to work in teams to promote effective management and safety in emergency departments. To address this issue, the implementation of interprofessional teamwork education is strongly recommended to help professionals develop the knowledge, skills, and attitudes that underlie effective teamwork in trauma care ${ }^{9}$. Simulations are commonly used for teamwork education in various healthcare settings ${ }^{10,11}$. Simulation training can be described on a continuum from low- to high- fidelity, which refers to the degree a simulation reproduces accurately the reality it aims to recreate ${ }^{12}$. When referring to high-fidelity simulation, simulation training often involves manikins capable of reproducing human reactions, thereby providing realtime information and feedback to learners ${ }^{13}$. Manikin-based high-fidelity simulation is particularly 
useful to reproduce critical clinical events requiring complex care procedures (i.e., intubation, chest tube placement). This form of training is also well-suited to practice concrete teamwork skills, such as communication and leadership ${ }^{14,15}$.

To date, two systematic reviews have examined the effectiveness of simulation training on teamwork and related behaviors or skills in trauma settings ${ }^{16,17}$. Both reviews came to similar conclusions: simulation is effective at improving teamwork (or non-technical skills). However, these reviews were not designed to capture several dimensions known to influence learning in simulation, such as the type of simulator, team composition and the environment. The eligibility criteria used in these reviews were broad and resulted in the inclusion of studies: 1) with pseudoteams (i.e., professionals from different healthcare disciplines who, unlike real trauma teams, do not usually work together); 2) with teams composed exclusively of nursing students (Barleycorn et al. ${ }^{16}$ only); and 3) in pediatric or military hospitals, which may not be representative of civilian adult trauma centers (Gjeraa et al. ${ }^{17}$ only). Another issue with these reviews is that no consideration was given to simulation design characteristics related to fidelity, such as the simulator, the participants or the environment, even if these characteristics are important factors for simulationbased learning ${ }^{18-20}$.

For those reasons, we decided to conduct a systematic review focusing specifically on the effect of interprofessional manikin-based simulation training on teamwork of real teams during trauma resuscitation in civilian, adult emergency departments.

\section{METHODS}

This systematic review was conducted according to the Joanna Briggs Institute Reviewer's Manual: Systematic Reviews of Effectiveness ${ }^{21}$; reporting is based on the Preferred Reporting Items for Systematic Reviews and Meta-Analyses (PRISMA) guidelines ${ }^{22}$. The review protocol was registered with PROSPERO (registration number not available at this time).

\section{Eligibility criteria}

The review considered all experimental (e.g., randomized controlled trial) and quasiexperimental studies (e.g., non-randomized controlled trial, pretest-posttest, and interrupted timeseries design) where the effectiveness of interprofessional manikin-based simulation training on teamwork outcomes was investigated in adult trauma emergency departments. Teamwork was 
defined as the interdependent actions and interactions among team members as they work towards achieving a common goal ${ }^{23}$.

\section{Population}

Based on the definition of 'trauma team' proposed by Engels et al. ${ }^{24}$, the population of interest included interprofessional teams of at least three different healthcare discipline (generally licensed doctors, nurses, and allied health personnel) working in adult trauma emergency departments. We decided to focus on simulations involving real trauma teams since it reflects the reality of training given in clinical settings and is known to enhance simulation fidelity ${ }^{60}$. Teams involving medical residents were included since residents are licensed physicians pursuing further training. Due to potential differences in the pedagogical intent of simulation training in prelicensure healthcare professionals, studies focusing exclusively on undergraduate students were excluded.

\section{Interventions}

To be included in this review, manikin-based simulation (i.e. high-fidelity simulator) scenarios had to involve an adult who suffered any type of potential life-threatening traumatic injury (e.g., polytrauma, traumatic brain injury, burn, spinal cord injury) requiring interprofessional resuscitation management in the emergency department. Simulations in laboratory settings or in real clinical settings (i.e., in situ) were both considered.

\section{Comparators}

When available, comparators included any other educational intervention.

\section{Outcomes}

The modified version of the Kirkpatrick's Levels of Evaluation model ${ }^{25}$, a model frequently used in simulation-based training ${ }^{26,27}$, was chosen as the framework to categorize outcomes. This model includes the following levels of educational outcomes: (1) learners' view and reaction to training, (2a) modification of attitudes/perceptions, (2b) acquisition of knowledge/skills, (3) behavioural change, (4a) change in organisational practice, and (4b) benefits to patients. Immediate acquisition of these outcomes (i.e., measured right after the simulation) or retention (i.e., measured after a period without simulation) were both of interest.

In healthcare professional education, teamwork competencies (e.g. knowledge, skills, and attitude [KSA] required for effective teamwork performance) are common educational outcomes $^{23,28}$. Team knowledge refers to cognitive processes, that is, key technical and contextual 
information, as well as the theories and concepts needed to be able to work as a team (e.g., shared mental models, understanding of team missions/objectives/norms) $)^{29,30}$. Team skills are the acts and procedures needed for teamwork (e.g., backup/supportive behavior, shared leadership, intrateam feedback) ${ }^{29}$. Team attitudes represent the affective attributes (i.e., emotions and attitudes) that drive effective teamwork (e.g., team empowerment, team goal commitment, mutual trust ${ }^{29}$. Studies targeting 'non-technical skills' or 'crisis resource management skills' were included, since those terms are often used to describe teamwork in the literature and refer to similar social and individual competencies involved in effective teamwork ${ }^{31,32}$.

For this review, the search strategy was constructed to retrieve studies evaluating outcomes directly related to teamwork in trauma resuscitation, i.e., changes from baseline in teamwork knowledge (level 2b), perception/attitude (2a), skills (2b), or behavior (3). Other changes indirectly related to teamwork such as learners' general reaction to simulation training (level 1), change in organizational practice (level 4a), and benefits for patients (level 4b) were also considered in the studies retrieved.

\section{Search strategy}

Six electronic databases-MEDLINE (Ovid), CINAHL, EMBASE (Ovid), EBM reviews, PsycINFO, and Citation Index Expanded Medline (Web of Science)—were searched using a combination of controlled descriptors (such as MeSH terms, CINAHL headings, and PsycINFO thesaurus) and keywords related to the following terms: trauma, wounds, injuries, simulation, mannequin, mannikin, team, interprofessional, interdisciplinary, multidisciplinary. A sample of the CINAHL search strategy is available in Appendix 1. No time limit was applied. The reference lists of all eligible studies and relevant reviews were hand-searched to identify additional studies. The search was restricted to papers published in English or French.

\section{Study selection}

Titles and abstracts of citations retrieved from the initial search were screened independently by two reviewers (AL and SB) using Covidence (Systematic Review Software, Veritas Health Innovation, Melbourne, Australia). Full texts of eligible citations were retrieved and assessed independently by the same reviewers based on the inclusion/exclusion criteria mentioned above. Disagreements at any stage of the selection process were resolved through discussion with a third reviewer (CA). For data that had been published more than once, only the most complete report was included in the review. 


\section{Quality assessment}

Methodological quality appraisal was carried out independently by two reviewers (AL and SB) using the Joanna Briggs Institute Critical Appraisal Tools. This tool includes questions to identify risk of bias on several aspects of RCT (13 questions) (e.g., randomization sequence allocation, allocation concealment, blinding, completeness of outcome data, selective outcome reporting) and quasi-experimental studies (9 questions) (e.g., selection bias, contamination bias, measurement bias, maturation threat). For each question, four answers are possible: Yes (clearly identifiable through the report description or confirmed by the primary author); Unclear (not clearly identified in the report and impossible to clarify with the author); No (not applied appropriately); and Not applicable. Disagreements arising between the reviewers were resolved through discussion, or with a third reviewer (CA). In addition, following Roberts et al. ${ }^{33}$ interpretation of quality appraisal, both reviewers determined, in discussion, what would constitute high-, moderateor low-quality scores. For RCT, high quality was defined as scores of 10 or more, while 7 to 9 scored as moderate quality and anything lower than 8 was considered low quality. For quasiexperimental studies, this resulted in scores of 8 or 9 defined as high quality, 6 or 7 as moderate quality, and any score lower than 6 as low quality.

\section{Data extraction and synthesis}

Data were extracted independently by two reviewers (AL and SB) using a validated tool ${ }^{34}$ which was adapted for the current review. The adapted tool included five domains: (1) identification of the study (title; journal; authors; country; year; host institution); (2) methodological characteristics (design; objectives; sample size; groups and controls; outcomes and measures); (3) simulation training characteristics following the reporting guidelines for health care simulation research ${ }^{35}$ (simulation environment; instructional design-duration, repetitions, nonsimulation interventions and adjuncts; debriefing); (4) main findings; and (5) study limitations. The two data extraction tables for a single paper were combined into one and disagreements were resolved through discussion or with a third reviewer (CA). Then, a narrative synthesis of the findings was performed, describing both consistencies and discrepancies between the studies. A meta-analysis was not possible given that the studies differed significantly with regards to interventions, purposes, and outcomes. The methodological quality of individual studies was summarized in the form of narrative statements and supported by a critical appraisal table. 


\section{RESULTS}

\section{Search results}

The initial search yielded a total of 2,064 potentially relevant citations from the following databases: MEDLINE 393, CINAHL 258, EMBASE 719, EBM review 85, PsycINFO 38, and Web of science 571. After removing duplicates, 1,120 citations were screened, resulting in the exclusions of 1,026 citations. A total of 94 full texts were assessed for eligibility and 11 papers were included in the final sample. The other 83 papers were excluded for the following reasons: (1) language ( $n=9$; not English or French), (2) publication type ( $n=20$; not research), (3) design ( $n=13$; not RCT or quasi-experimental study), (4) research context ( $n=5$; not in adult emergency departments), (5) intervention type ( $n=9$; not manikin-based simulation), (6) outcomes ( $n=27$; not teamwork-related). The screening and selection process followed the PRISMA Checklist (Figure 1). Hand-search of included studies did not yield new references.

\section{Figure 1. PRISMA flow chart}

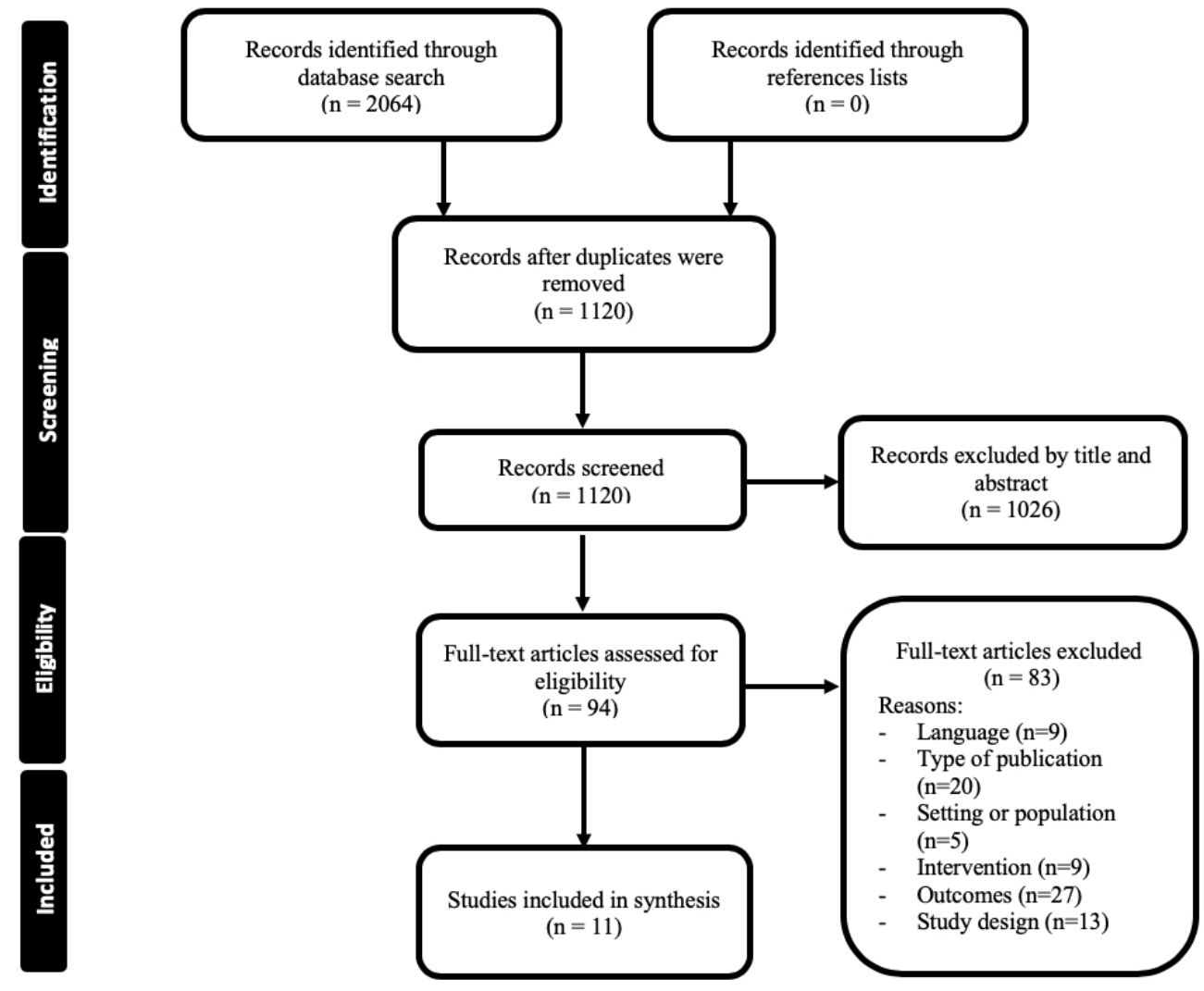

\section{Study characteristics}

All studies were published in peer-reviewed journals between 2010-2019. Seven studies were carried out in the United States ${ }^{36-42}$, two in Canada $^{43,44}$, one in Israel ${ }^{45}$, and one in Finland ${ }^{46}$. 
The majority $(n=7)^{36,37,40,43-46}$ used a pre-test/posttest, quasi-experimental design without a comparison group. The remaining studies $(n=4)^{38,39,41,42}$ used longitudinal designs to evaluate teamwork during real trauma resuscitation and at different time-points after training (ranging anywhere from four weeks to twelve months after), without a comparison group. When specified, sample sizes varied greatly, ranging from 24 to 430 trauma care professionals. All studies used a convenience sample. In terms of team constitution, all studies used already existing teams; and only one study randomly assigned professionals to simulation teams ${ }^{45}$. While the inclusion of medical residents was common $(n=8 / 11)^{36,37,39-44}$, only one study ${ }^{40}$ included undergraduate nursing students (see Table, Supplemental Digital Content 1, for detailed information on the studies characteristics).

\section{Simulation design characteristics}

All simulations used high-fidelity manikins (mostly SimMan® 3G, Laerdal Medical). Trauma teams were most often composed of more than five professionals $(n=6 / 11)^{36,39,42-45}$ from three or more disciplines (i.e., surgery, emergency medicine, nursing, and other allied health workers). Five studies used in situ simulations ${ }^{37,39,42,45,46}$ (e.g., in the actual patient care environment), four used a laboratory setting (sometimes referred to as a simulation center) $36,40,43,44$, one used an on-site simulation ${ }^{38}$ (e.g., performed in an unused room in the emergency department that was repurposed for simulation ${ }^{47}$ ), and one used two different environments for the same simulation scenario ${ }^{41}$ (laboratory and in situ).

Other instructional design characteristics presented a high level of heterogeneity. Training programs lasted anywhere from one hour to one day, with most $(n=6 / 11)^{36,38,39,42-45}$ extending over four hours. Miller et al. ${ }^{39}$ was the only study who evaluated a complete simulation program (i.e., weekly trauma simulation of one hour each over eight weeks). Eight studies included a didactic phase delivered through lectures or presentations before the simulation ${ }^{36,38,39,41-44,46}$. The main themes addressed during the didactic phase were trauma team roles and responsibilities ${ }^{36,39,43,44}$, TeamSTEPPS principles ${ }^{36,38,41}$, basic CRM principles $^{43,44}$ and nurse's role in trauma quality improvement ${ }^{38}$. All of the studies included a debriefing session after the simulation exercises. However, only two studies ${ }^{37,38}$ mentioned the debriefing method used: the $4 \mathrm{E}$ method ${ }^{48}$, and the Plus-Delta ${ }^{49}$. Of note, two studies ${ }^{43,44}$ evaluated the same educational intervention, the S.T.A.R.T.T. (Simulated Trauma and Resuscitative Team Training) course, but did not assess the 
same outcomes; therefore, both were included in the review (see Table, Supplemental Digital Content 1 , for detailed information on the simulation characteristics).

\section{Risk of bias}

Since all studies used quasi-experimental designs, methodological quality of the quantitative studies was assessed with the JBI Critical Appraisal Checklist for Quasi-Experimental Studies $^{21}$. Methodological quality ranged from low to moderate (see Table 1).

Attrition bias (question 6) was not applicable in six studies ${ }^{37,40,43-46}$ since those studies' design involved assessments before and immediately after the simulations. For studies with multiple post-intervention assessments, this item could not be assessed since participants' characteristics were not specified ${ }^{36,38,39,42}$. For measurement bias (question 8), studies $(n=2)^{37,43}$ including only participant self-assessments were considered at risk. The remaining studies $(n=9)^{36,38-42,44-46}$ included observer assessments, mostly from trained simulation instructors-only one of those studies did not report on the training of observers ${ }^{44}$. In addition, two out of five studies $^{42,46}$ reported poor inter-rater-reliability (ICC $<0.5$ ), increasing the risk of measurement bias. Three studies ${ }^{36,38,40}$ did not mention any analysis of inter-rater-reliability. Finally, only two studies $^{38,39}$ reported psychometric properties of the assessment tools that were used, making it difficult to fully appreciate the study results ${ }^{50}$.

\section{Teamwork definition and assessment of outcomes}

Almost all studies $(n=7)$ used the concept of 'teamwork' $36,38-42,45$, but did not provide an explicit conceptual framework or operational definition. However, three studies ${ }^{36,38,41}$ referred to the Team Strategies and Tools to Enhance Performance and Patient Safety (TeamSTEPPS) curriculum (i.e., a comprehensive set of material and training curriculum which seeks to enhance patient safety through the use of team-based principles) in their intervention design ${ }^{51}$. Two studies focused on 'non-technical skills (NTS)' and 'crisis resource management (CRM) skills'. Gardner et al. ${ }^{37}$ used a concept that they associated with teamwork knowledge: 'transactive memory system'-e.g., a combination of the knowledge possessed by each individual and a collective awareness of where knowledge resides within the team. Three studies ${ }^{39,40,45}$ did not use any form of framework. 
Table 1. Critical appraisal for quasi-experimental studies

\begin{tabular}{|c|c|c|c|c|c|c|c|c|c|c|c|c|}
\hline $\begin{array}{c}\text { Questions } \\
\text { (potential } \\
\text { bias and } \\
\text { threats) }\end{array}$ & $\begin{array}{l}\text { Amiel } \\
(2015)\end{array}$ & $\begin{array}{c}\text { Capella } \\
(2010)\end{array}$ & $\begin{array}{c}\text { Gardner } \\
\text { (2014) }\end{array}$ & $\begin{array}{l}\text { Gillman } \\
(2016)\end{array}$ & $\begin{array}{r}\text { Harvey } \\
(2019)\end{array}$ & $\begin{array}{l}\text { Miller } \\
(2012)\end{array}$ & $\begin{array}{l}\text { Paige } \\
(2019)\end{array}$ & $\begin{array}{c}\text { Roberts } \\
(2014)\end{array}$ & $\begin{array}{l}\text { Rosqvist } \\
\text { (2019) }\end{array}$ & $\begin{array}{l}\text { Steinemann } \\
\quad(2011)\end{array}$ & $\begin{array}{l}\text { Ziesmann } \\
\text { (2013) }\end{array}$ & $\begin{array}{c}\text { Total } \\
(\%)\end{array}$ \\
\hline 1 & $\mathrm{Y}$ & $\mathrm{Y}$ & $Y$ & $Y$ & $\mathrm{Y}$ & $\mathrm{Y}$ & $\mathrm{Y}$ & $\mathrm{Y}$ & $\mathrm{Y}$ & $\mathrm{Y}$ & $\mathrm{Y}$ & $100 \%$ \\
\hline 2 & Y & $\mathrm{U}$ & Y & $Y$ & $\mathrm{U}$ & $\mathrm{U}$ & $\mathrm{Y}$ & Y & Y & $\mathrm{U}$ & $\mathrm{Y}$ & $63 \%$ \\
\hline 3 & $\mathrm{U}$ & Y & $\mathrm{Y}$ & Y & $\mathrm{Y}$ & $\mathrm{Y}$ & $\mathrm{Y}$ & $\mathrm{Y}$ & $\mathrm{U}$ & $\mathrm{Y}$ & Y & $82 \%$ \\
\hline 4 & $\mathrm{~N}$ & $\mathrm{~N}$ & $\mathrm{~N}$ & $\mathrm{~N}$ & $\mathrm{~N}$ & $\mathrm{~N}$ & $\mathrm{~N}$ & $\mathrm{~N}$ & $\mathrm{~N}$ & $\mathrm{~N}$ & $\mathrm{~N}$ & $0 \%$ \\
\hline 5 & $\mathrm{~N}$ & $\mathrm{Y}$ & $\mathrm{N}$ & $\mathrm{Y}$ & $\mathrm{Y}$ & $\mathrm{Y}$ & $\mathrm{N}$ & $\mathrm{Y}$ & $\mathrm{N}$ & $\mathrm{Y}$ & $\mathrm{N}$ & $55 \%$ \\
\hline 6 & NA & $\mathrm{N}$ & NA & NA & $\mathrm{U}$ & $\mathrm{U}$ & NA & $Y$ & NA & $\mathrm{N}$ & NA & $20 \%$ \\
\hline 7 & $\mathrm{Y}$ & $\mathrm{Y}$ & $\mathrm{Y}$ & $\mathrm{Y}$ & $\mathrm{Y}$ & $\mathrm{Y}$ & $\mathrm{Y}$ & $\mathrm{Y}$ & $\mathrm{Y}$ & $\mathrm{Y}$ & $\mathrm{Y}$ & $100 \%$ \\
\hline 8 & $\mathrm{Y}$ & $\mathrm{Y}$ & $\mathrm{N}$ & $\mathrm{U}$ & $\mathrm{Y}$ & $\mathrm{Y}$ & $\mathrm{Y}$ & $\mathrm{N}$ & $\mathrm{N}$ & $\mathrm{N}$ & $\mathrm{N}$ & $45 \%$ \\
\hline 9 & $Y$ & $\mathrm{Y}$ & $Y$ & $\mathrm{Y}$ & $Y$ & $\mathrm{Y}$ & $\mathrm{Y}$ & $Y$ & $Y$ & $Y$ & $\mathrm{Y}$ & $100 \%$ \\
\hline \multirow[t]{2}{*}{ TOTAL } & $5 / 8$ & $6 / 8$ & $5 / 8$ & $6 / 8$ & $6 / 9$ & $6 / 9$ & $6 / 8$ & $7 / 9$ & $4 / 8$ & $5 / 8$ & $5 / 8$ & \\
\hline & Mod & Mod & Mod & Mod & Mod & Mod & Mod & Mod & Low & Mod & Mod & \\
\hline
\end{tabular}

Y: Yes, N: No, U: Unclear; NA: Not applicable, Mod: Moderate

Q1. Is it clear in the study what is the 'cause' and what is the 'effect'? (causation/reverse causation)

Q2. Were the participants included in any comparisons similar? (selection bias)

Q3. Were the participants included in any comparisons receiving similar treatment/care, other than the exposure or intervention of interest?

(history threat/systematic difference/contamination bias)

Q4. Was there a control group? (measurement bias)

Q5. Were there multiple measurements of the outcome both pre and post the intervention/exposure? (maturation threat, regression to the mean)

Q6. Was follow up complete and if not, were differences between groups in terms of their follow up adequately described and analyzed? (attrition bias)

Q7. Were the outcomes of participants included in any comparisons measured in the same way? (instrumentation/testing effects threats)

Q8. Were outcomes measured in a reliable way? (detection/instrument/measurement bias)

Q9. Was appropriate statistical analysis used? (performance/detection bias 
Most studies $(n=7)$ assessed more than one outcome related to teamwork. Two studies assessed learners' reaction to training (level 1) ${ }^{38,44}$; five assessed modifications in attitudes/perceptions (level 2a) ${ }^{38,40,41,43,46}$; eight assessed the acquisition of knowledge/skills (level 2b) 37,38,40-42,44-46; four assessed behavioral change (level 3) 36,38,39,42; one assessed changes in organizational practice (level 4a) ${ }^{36}$; and one assessed benefits to patients/clients (level $\left.4 b\right)^{36}$ (see Table, Supplemental Digital Content 1, for a summary of the outcome levels assessed in the studies).

\section{Direct Outcomes}

Level $2 \boldsymbol{a}$. Five studies ${ }^{38,40,41,43,46}$ assessed the effect of manikin-based simulations on teamwork perception (i.e., participants' confidence, self-efficacy in teamwork, perception of their real-life trauma resuscitation-related to teamwork or NTS) or attitudes (i.e., intention to apply new knowledge and skills, attitude towards knowledge and skills learned, and readiness for interprofessional learning) (Table 2). Two studies ${ }^{38,40}$ reported the use of a validated toolsincluding the Brief-TeamSTEPPS Teamwork Perception questionnaire (Brief-T-TPQ) ${ }^{52}$, the Teamwork Assessment Scales (TAS) ${ }^{53}$, and the Readiness for Interprofessional Learning Scale $(\text { RIPLS })^{54}$ — and three studies ${ }^{33,38,46}$ used questionnaires and surveys designed for the study with no published validity data, such as the Interprofessional Teamwork questionnaire (IPT) ${ }^{40}$.

Most studies $(n=5)^{38,40,41,43,46}$ showed immediate improvement in teamwork perception and attitude after training. However, one of these studies ${ }^{40}$ found significant improvement in only two of the 19 items on the Readiness for Interprofessional Learning Scale (RIPLS) (i.e., (1) 'Shared learning with other healthcare students will increase my ability to understand clinical problems' and (2) 'I would welcome the opportunity to work on small-group projects with other healthcare students'). Harvey et al. ${ }^{38}$ found no difference in the Brief-T-TPQ scores between resident and nurses, and between the three time periods (baseline, six months, 12 months). Rosqvist et al. ${ }^{46}$ found that all NTS performance perceptions improved after simulation, except the teamwork/cooperation between specialists and residents, and time management among nurses. In the same study, Rosqvist et al. ${ }^{46}$ observed differences between disciplines: specialists and residents mostly improved in time management, knowledge of the trauma resuscitation guidelines, and problem identification, while nurses and nursing students mostly improved in knowledge of the trauma resuscitation guidelines, decision making, communication, and interaction. 
Table 2. LEVEL 2 A: Modification of teamwork attitudes/perceptions

\begin{tabular}{|c|c|c|c|c|c|}
\hline Reference & $\begin{array}{c}\text { Main outcome } \\
\text { evaluated }\end{array}$ & Tools & $\begin{array}{c}\text { Timing of } \\
\text { evaluation }\end{array}$ & Assessors & Results \\
\hline \multirow{2}{*}{$\begin{array}{l}\text { Harvey et } \\
\text { al. (2019) }\end{array}$} & $\begin{array}{l}\text { Teamwork } \\
\text { perception }\end{array}$ & $\begin{array}{l}\text { Brief- } \\
\text { TeamSTEPPS } \\
\text { Teamwork } \\
\text { Perception } \\
\text { questionnaire (B- } \\
\text { T-TPQ) }^{1}\end{array}$ & $\begin{array}{l}\text { Pre } \\
\text { training, } 6 \\
\text { and } 12 \\
\text { months } \\
\text { after } \\
\text { training. }\end{array}$ & $\begin{array}{l}\text { Participant's } \\
\text { self- } \\
\text { assessment }\end{array}$ & $\begin{array}{l}\text { Scores did not } \\
\text { differ between } \\
\text { resident } \\
\text { physicians and } \\
\text { nurses nor in the } \\
\text { three time period } \\
\text { groups. }\end{array}$ \\
\hline & $\begin{array}{l}\text { Confidence in } \\
\text { technical and } \\
\text { nontechnical } \\
\text { teamwork skills } \\
\text { (only nurses) }\end{array}$ & $\begin{array}{l}\text { Trauma RN } \\
\text { Confidence } \\
\text { Survey (designed } \\
\text { for the study) }\end{array}$ & $\begin{array}{l}\text { Before and } \\
\text { after } \\
\text { training }\end{array}$ & $\begin{array}{l}\text { Participant's } \\
\text { self- } \\
\text { assessment }\end{array}$ & $\begin{array}{l}\text { Trauma nurse } \\
\text { confidence scores } \\
\text { increased } \\
\text { significantly after } \\
\text { training for all } \\
\text { technical skills } \\
\text { and NTS. }\end{array}$ \\
\hline \multirow{3}{*}{$\begin{array}{l}\text { Paige et } \\
\text { al. (2019) }\end{array}$} & $\begin{array}{l}\text { Perception of } \\
\text { individual and } \\
\text { team simulation } \\
\text { performance }\end{array}$ & $\begin{array}{l}\text { Teamwork } \\
\text { Assessment } \\
\text { Scales (TAS) }\end{array}$ & $\begin{array}{l}\text { After each } \\
\text { scenario }\end{array}$ & $\begin{array}{l}\text { Participant's } \\
\text { self and peer } \\
\text { assessment }\end{array}$ & $\begin{array}{l}\text { Self- and peer- } \\
\text { assessments mean } \\
\text { scores improved } \\
\text { significantly on } \\
\text { all subscales from } \\
\text { scenario } 1 \text { to } \\
\text { scenario } 2 .\end{array}$ \\
\hline & $\begin{array}{l}\text { Interprofessional } \\
\text { attitudes }\end{array}$ & $\begin{array}{l}\text { Readiness for } \\
\text { Interprofessional } \\
\text { Learning Scale } \\
\text { (RIPLS) } \\
\text { questionnaire }^{2}\end{array}$ & $\begin{array}{l}\text { Before and } \\
\text { after } \\
\text { training }\end{array}$ & $\begin{array}{l}\text { Participant's } \\
\text { self- } \\
\text { assessment }\end{array}$ & $\begin{array}{l}\text { Significant } \\
\text { improvement on } \\
\text { 2/19 items. }\end{array}$ \\
\hline & $\begin{array}{l}\text { Interprofessional } \\
\text { teamwork self- } \\
\text { efficacy }\end{array}$ & $\begin{array}{l}\text { Interprofessional } \\
\text { Teamwork (IPT) } \\
\text { questionnaire } \\
\text { (designed for the } \\
\text { study) }\end{array}$ & $\begin{array}{l}\text { Before and } \\
\text { after } \\
\text { training }\end{array}$ & $\begin{array}{l}\text { Participant's } \\
\text { self- } \\
\text { assessment }\end{array}$ & $\begin{array}{l}\text { Significant } \\
\text { improvement on } \\
\text { all } 15 \text { items. }\end{array}$ \\
\hline $\begin{array}{l}\text { Roberts et } \\
\text { al. (2014) }\end{array}$ & $\begin{array}{l}\text { Intention to apply } \\
\text { knowledge and } \\
\text { skills learned } \\
\text { Attitudes } \\
\text { regarding the } \\
\text { knowledge and } \\
\text { skills learned } \\
\end{array}$ & $\begin{array}{l}\text { Questionnaires } \\
\text { (designed for the } \\
\text { study) }\end{array}$ & $\begin{array}{l}\text { After } \\
\text { training }\end{array}$ & $\begin{array}{l}\text { Participant's } \\
\text { self- } \\
\text { assessment }\end{array}$ & $\begin{array}{l}\text { For all questions, } \\
\text { the most frequent } \\
\text { response was } \\
\text { 'strongly agree'. }\end{array}$ \\
\hline $\begin{array}{l}\text { Rosqvist } \\
\text { et al. } \\
(2019)\end{array}$ & $\begin{array}{l}\text { Perception of NTS } \\
\text { performance } \\
\text { during real-life } \\
\text { trauma } \\
\text { resuscitation }\end{array}$ & $\begin{array}{l}\text { Self-assessment } \\
\text { questionnaire } \\
\text { (designed for the } \\
\text { study) }\end{array}$ & $\begin{array}{l}\text { Before and } \\
\text { after } \\
\text { training }\end{array}$ & $\begin{array}{l}\text { Participant's } \\
\text { self- } \\
\text { assessment }\end{array}$ & $\begin{array}{l}\text { Participants' } \\
\text { perception of } \\
\text { NTS improved } \\
\text { significantly, } \\
\text { except teamwork- } \\
\text { cooperation } \\
\text { among specialists } \\
\text { and residents and }\end{array}$ \\
\hline
\end{tabular}


time management

among nurses/nursing students.

Significant

Attitudes toward

Ziesmann CRM principles in et al. (2013) (teamwork, safety climate and stress recognition) improvement in attitudes toward

Attitude Survey

Before and

Participant's

selfassessment
CRM in the domains of teamwork and safety climate; no improvement for stress recognition.

NTS: Non-technical skills; CRM: Crisis resource management; RN: Registered nurse

Level $2 \boldsymbol{b}$. Six studies ${ }^{40-42,44-46}$ assessed acquisition of skills in simulations and one $\mathrm{e}^{37}$ assessed acquisition of knowledge related to 'transactive memory' via a self-rated questionnaire (Table 3). Four studies ${ }^{40,42,44,46}$ used a validated tool to rate or observe teamwork skills in simulation, including the Ottawa global rating scale (GRS) ${ }^{55}$, the Teamwork Assessment Scales (TAS) ${ }^{53}$, and the Trauma Non-Technical skills scale (T-NOTECHS) ${ }^{56}$. One study ${ }^{41}$ measured the frequency of trained behaviors and the quality of their execution via video recordings of simulation by two trained and blinded observers, a surgeon and a nurse. Most studies used a trained observer $(n=5 / 7)^{40-42,45,46}$, but one did not report observer's training ${ }^{44}$.

All seven studies showed a significant improvement in overall teamwork skills or knowledge immediately after training, from both participants' and observers' assessments. Six studies assessed teamwork skills ${ }^{40-42,44-46}$. Four ${ }^{40,42,44,46}$ compared the improvement of skills in multiple simulation scenarios (i.e., two and four scenarios). One ${ }^{45}$ averaged teamwork skills scores on pre- and post-tests (four simulations). One ${ }^{41}$ reassembled the same participants for another simulation to measure retention of skills related to team behaviors in a simulation setting (three weeks post training). They found that when comparing the pretraining scores with the three-week retention results, seven areas out of 17 had lasting training effects: 'communication', 'cooperation', 'situation awareness', 'listened to information', 'organized', 'efficiency', and 'instructions performed', all critical indicators of effective teamwork performance. For transactive memory assessment, Gardner et al. ${ }^{37}$ showed that coordination (i.e., ability of team members to work together efficiently) and credibility (i.e., the degree to which group members trusted one another's 
expertise) increased significantly for all four groups, while only two groups showed a significant increase in specialization (i.e., acknowledgment of distributed expertise within the team).

Table 3. LEVEL 2B: Acquisition of knowledge/skills

\begin{tabular}{|c|c|c|c|c|c|}
\hline Reference & $\begin{array}{l}\text { Main outcome } \\
\text { evaluated } \\
\text { (and how) }\end{array}$ & Tools & $\begin{array}{l}\text { Timing of } \\
\text { evaluation }\end{array}$ & Assessors & Results \\
\hline $\begin{array}{l}\text { Amiel et al. } \\
(2015)\end{array}$ & $\begin{array}{l}\text { Teamwork and } \\
\text { communication } \\
\text { skills } \\
\text { (in situ simulation) }\end{array}$ & $\begin{array}{l}\text { Score on a } \\
\text { Likert scale } \\
\text { from } 1 \text { to } 10\end{array}$ & $\begin{array}{l}\text { Before and } \\
\text { after training }\end{array}$ & $\begin{array}{l}\text { Participants } \\
\text { and } 4 \text { trained } \\
\text { instructors }\end{array}$ & $\begin{array}{l}\text { Trainees self- } \\
\text { assessment } \\
\text { improved } \\
\text { markedly after } \\
\text { training. } \\
\text { Instructors scores } \\
\text { showed } 29.64 \% \\
\text { improvement for } \\
\text { teamwork and } \\
24.48 \% \text { for } \\
\text { communication, } \\
\text { both significant. }\end{array}$ \\
\hline $\begin{array}{l}\text { Gardner et } \\
\text { al. (2014) }\end{array}$ & $\begin{array}{l}\text { Transactive } \\
\text { memory } \\
\text { (specialization, } \\
\text { team coordination } \\
\text { and credibility) } \\
\text { (questionnaire) }\end{array}$ & $\begin{array}{l}15 \text { items } \\
\text { questionnaire } \\
\text { to assess three } \\
\text { dimensions of } \\
\text { Transactive } \\
\text { memory }\end{array}$ & $\begin{array}{l}\text { Before and } \\
\text { after training }\end{array}$ & $\begin{array}{l}\text { Participant's } \\
\text { self- } \\
\text { assessment }\end{array}$ & $\begin{array}{l}\text { For all } 4 \text { groups, } \\
\text { coordination and } \\
\text { credibility } \\
\text { increased } \\
\text { significantly after } \\
\text { training. Only } 2 / 4 \\
\text { groups showed a } \\
\text { significant } \\
\text { increase in } \\
\text { specialization. }\end{array}$ \\
\hline $\begin{array}{l}\text { Gillman et } \\
\text { al. (2016) }\end{array}$ & $\begin{array}{l}\text { CRM skills in } 5 \\
\text { categories } \\
\text { including } \\
\text { leadership skills, } \\
\text { communication } \\
\text { skills and overall } \\
\text { performance } \\
\text { (in simulation) }\end{array}$ & $\begin{array}{l}\text { Ottawa global } \\
\text { rating scale } \\
(\mathrm{GRS})^{1}\end{array}$ & $\begin{array}{l}\text { After each } \\
\text { scenario }\end{array}$ & $\begin{array}{l}\text { A single } \\
\text { observer }\end{array}$ & $\begin{array}{l}\text { Significant score } \\
\text { improvement } \\
\text { between the } 1^{\text {st }} \\
\text { and } 3^{\text {rd }}, 2^{\text {nd }} \text { and } \\
3^{\text {rd }} \text {, and } 2^{\text {nd }} \text { and } 4^{\text {th }} \\
\text { scenarios. }\end{array}$ \\
\hline $\begin{array}{l}\text { Paige et al. } \\
\text { (2019) }\end{array}$ & $\begin{array}{l}\text { Individual and } \\
\text { team performance } \\
\text { (in simulation) }\end{array}$ & $\begin{array}{l}\text { Teamwork } \\
\text { Assessment } \\
\text { Scales (TAS) }\end{array}$ & $\begin{array}{l}\text { After each } \\
\text { scenario }\end{array}$ & $\begin{array}{l}2 \text { trained } \\
\text { instructors }\end{array}$ & $\begin{array}{l}\text { Significant mean } \\
\text { score } \\
\text { improvement on } \\
\text { most subscale } \\
\text { from scenario } 1 \text { to } \\
\text { scenario } 2 \text {, except } \\
\text { for team-based } \\
\text { behaviors. }\end{array}$ \\
\hline
\end{tabular}




\begin{tabular}{|c|c|c|c|c|c|}
\hline $\begin{array}{l}\text { Roberts et } \\
\text { al. (2014) }\end{array}$ & $\begin{array}{l}\text { Changes in team } \\
\text { and leader } \\
\text { behaviors } \\
\text { (in simulation) }\end{array}$ & $\begin{array}{l}\text { Video records } \\
\text { of simulation } \\
\text { (coded } \\
\text { frequencies of } \\
\text { trained } \\
\text { behaviors and } \\
\text { quality of those } \\
\text { performances) }\end{array}$ & $\begin{array}{l}\text { Before, } \\
\text { immediately } \\
\text { after, and } 3 \\
\text { weeks after } \\
\text { training }\end{array}$ & $\begin{array}{l}\text { Trained and } \\
\text { blinded } \\
\text { (stage of } \\
\text { training) } \\
\text { surgeon and } \\
\text { a nurse }\end{array}$ & $\begin{array}{l}15 / 17 \text { team and } \\
\text { leader behaviors } \\
\text { improved } \\
\text { immediately after } \\
\text { training. Results } \\
\text { were sustained } \\
\text { after } 3 \text { weeks for } \\
7 / 17 \text { behaviors. }\end{array}$ \\
\hline $\begin{array}{l}\text { Rosqvist et } \\
\text { al. (2019) }\end{array}$ & $\begin{array}{l}\text { Teamwork skills } \\
\text { (leadership, } \\
\text { cooperation and } \\
\text { resource } \\
\text { management, } \\
\text { communication and } \\
\text { interaction, } \\
\text { assessment and } \\
\text { decision making, } \\
\text { situation } \\
\text { awareness/coping } \\
\text { with stress) } \\
\text { (in simulation) }\end{array}$ & $\begin{array}{l}\text { Trauma Non- } \\
\text { Technical } \\
\text { Skills Scale (T- } \\
\text { NOTECHS) }\end{array}$ & $\begin{array}{l}\text { Before and } \\
\text { after training }\end{array}$ & $\begin{array}{l}2 \text { expert } \\
\text { observers }\end{array}$ & $\begin{array}{l}\text { All scores } \\
\text { improved } \\
\text { significantly. }\end{array}$ \\
\hline $\begin{array}{l}\text { Steinemann } \\
\text { et al. } \\
(2011)\end{array}$ & $\begin{array}{l}\text { Teamwork skills } \\
\text { (leadership, } \\
\text { cooperation and } \\
\text { resource } \\
\text { management, } \\
\text { communication and } \\
\text { interaction, } \\
\text { assessment and } \\
\text { decision making, } \\
\text { situation } \\
\text { awareness/coping } \\
\text { with stress) } \\
\text { (in simulation and } \\
\text { in real life) }\end{array}$ & $\begin{array}{l}\text { Trauma Non- } \\
\text { Technical } \\
\text { Skills Scale (T- } \\
\text { NOTECHS) }\end{array}$ & $\begin{array}{l}\text { After first } \\
\text { scenario and } \\
\text { last scenario }\end{array}$ & $\begin{array}{l}13 \text { trained } \\
\text { critical care } \\
\text { nurses and } 4 \\
\text { research } \\
\text { assistants }\end{array}$ & $\begin{array}{l}\text { Significant } \\
\text { improvement in } \\
\text { mean scores } \\
\text { between first and } \\
\text { last scenario. }\end{array}$ \\
\hline
\end{tabular}

CRM: Crisis resource management

Level 3. For behavioral changes in clinical practice, four studies $36,38,39,42$ assessed participants teamwork skills in real trauma resuscitation with validated tools, including the Trauma Team Performance Observation Tool (T-TPOT) ${ }^{57}$, the Clinical Teamwork Scale (CTS) ${ }^{58}$, and the Trauma Non-Technical skills scale (T-NOTECHS) ${ }^{56}$ (Table 4). Harvey et al. ${ }^{38}$ assessed teamwork performance with the T-TPOT at multiple time-points (before training, as well as 6 months and 12 months after) to document behavior retention. Overall, results showed significant improvement in teamwork performance at six months but significant decline at 12 months. Three studies compared baseline scores with post-simulation mean scores from data gathered at different time-points. 
Steinemann et al. ${ }^{42}$ and Capella et al. ${ }^{36}$ found a significant long-term improvement in mean TNOTECHS and T-TPOT scores, when comparing average scores gathered four-seven months prior training with average scores gathered three-eight months post-training. Miller et al. ${ }^{39}$ compared average scores during 39 resuscitations at different time points (i.e., pre-training, after didactic training only, after in situ simulation training, and one-week after simulation-during 4 weeks). Results showed that scores for 11 of 14 measures of the CTS improved from pre-training to the didactic training phase. While the scores of all CTS component measures were the highest during the in-situ simulation phase, all declined to baseline values during the 'one-week after simulation' phase, demonstrating no behaviours' retention over time.

Table 4. LEVEL 3: Behavioural change

\begin{tabular}{|c|c|c|c|c|c|}
\hline Reference & $\begin{array}{l}\text { Main outcome } \\
\text { assessed } \\
\text { (and how) }\end{array}$ & Tools & $\begin{array}{c}\text { Timing of } \\
\text { evaluation/ } \\
\text { Sample of } \\
\text { observation }\end{array}$ & Assessors & Results \\
\hline $\begin{array}{l}\text { Capella et } \\
\text { al. (2010) }\end{array}$ & $\begin{array}{l}\text { Teamwork skills } \\
\text { (leadership, mutual } \\
\text { support, situation } \\
\text { monitoring, } \\
\text { communication) (in } \\
\text { real clinical } \\
\text { practice) }\end{array}$ & $\begin{array}{l}\text { Trauma } \\
\text { Team } \\
\text { Performance } \\
\text { Observation } \\
\text { Tool (T- } \\
\text { TPOT) }^{1}\end{array}$ & $\begin{array}{l}\text { Before (4 } \\
\text { months; } \\
\mathrm{n}=33) \text { and } \\
\text { after the } \\
\text { training } \\
\text { session ( } 3 \\
\text { months; } \\
\mathrm{n}=40)\end{array}$ & $\begin{array}{l}\text { Trained } \\
\text { evaluators }\end{array}$ & $\begin{array}{l}\text { Team } \\
\text { performance } \\
\text { improved } \\
\text { significantly } \\
\text { across all } \\
\text { domains. }\end{array}$ \\
\hline $\begin{array}{l}\text { Harvey et } \\
\text { al. (2019) }\end{array}$ & $\begin{array}{l}\text { Teamwork skills } \\
\text { (leadership, } \\
\text { situation } \\
\text { monitoring, mutual } \\
\text { support, } \\
\text { communication) (in } \\
\text { real clinical } \\
\text { practice) }\end{array}$ & $\begin{array}{l}\text { Trauma } \\
\text { Team } \\
\text { Performance } \\
\text { Observation } \\
\text { Tool (T- } \\
\text { TPOT) }^{1}\end{array}$ & $\begin{array}{l}\text { Before } \\
\text { training (one } \\
\text { month; } n= \\
\text { NR), } 6 \text { (one } \\
\text { month; } \\
\text { n=NR) and } \\
12 \text { months } \\
\text { (one month; } \\
\text { n=NR) after } \\
\text { training. }\end{array}$ & $\begin{array}{l}\text { Local } \\
\text { TeamSTEPPS } \\
\text { Master } \\
\text { Trainers/trauma } \\
\text { clinical care } \\
\text { experts }\end{array}$ & $\begin{array}{l}\text { Total scores at } 6 \\
\text { months post- } \\
\text { training were } \\
\text { significantly } \\
\text { higher than pre- } \\
\text { training. Scores } \\
\text { regressed to } \\
\text { baseline at } 12 \\
\text { months } \\
\text { postintervention }\end{array}$ \\
\hline $\begin{array}{l}\text { Miller et al. } \\
\text { (2012) }\end{array}$ & $\begin{array}{l}\text { Clinical teamwork } \\
\text { (in real clinical } \\
\text { practice) }\end{array}$ & $\begin{array}{l}\text { Clinical } \\
\text { Teamwork } \\
\text { Scale }(\mathrm{CTS})^{2} \\
\text { measuring } \\
14 \text { items of } \\
\text { teamwork }\end{array}$ & $\begin{array}{l}\text { Pre- } \\
\text { intervention } \\
\text { ( } 4 \text { months), } \\
\text { didactic-only } \\
\text { phase ( } 4 \\
\text { months), in } \\
\text { situ } \\
\text { simulation } \\
\text { phase ( } 3 \\
\text { months and }\end{array}$ & $\begin{array}{l}3 \text { Trauma } \\
\text { Nursing Core } \\
\text { Course } \\
\text { certified nurses } \\
\text { trained on use } \\
\text { of the CTS }\end{array}$ & $\begin{array}{l}\text { Scores on } 11 \text { of } \\
14 \text { items } \\
\text { improved (1 } \\
\text { significantly: } \\
\text { closed loop } \\
\text { communication) } \\
\text { from baseline to } \\
\text { didactic phase. } \\
12 / 14 \text { scores } \\
\text { improved }\end{array}$ \\
\hline
\end{tabular}




\begin{tabular}{|c|c|c|c|c|c|}
\hline & & & $\begin{array}{l}\text { post phase (1 } \\
\text { week after } \\
\text { simulation, } \\
\text { lasting } 4 \\
\text { weeks). } \\
\mathrm{n}=39\end{array}$ & & $\begin{array}{l}\text { significantly } \\
\text { from baseline to } \\
\text { in situ simulation } \\
\text { phase. In the } \\
\text { post-phase, all } \\
\text { scores were } \\
\text { similar to } \\
\text { baseline. }\end{array}$ \\
\hline $\begin{array}{l}\text { Steinemann } \\
\text { et al. } \\
\text { (2011) }\end{array}$ & $\begin{array}{l}\text { Teamwork } \\
\text { (leadership, } \\
\text { cooperation and } \\
\text { resource } \\
\text { management, } \\
\text { communication and } \\
\text { interaction, } \\
\text { assessment and } \\
\text { decision making, } \\
\text { situation } \\
\text { awareness/coping } \\
\text { with stress) (in } \\
\text { simulation and in } \\
\text { real life) }\end{array}$ & $\begin{array}{l}\text { Trauma } \\
\text { Non- } \\
\text { Technical } \\
\text { skills scale } \\
(\text { T- } \\
\text { NOTECHS })^{3}\end{array}$ & $\begin{array}{l}\text { Before } \\
\text { training ( } 6 \\
1 / 2 \text { months; } \\
\mathrm{n}=141) \text { and } \\
\text { after }(8 \\
\text { months; } \\
\mathrm{n}=103)\end{array}$ & $\begin{array}{l}13 \text { trained } \\
\text { critical care } \\
\text { nurses and } 4 \\
\text { research } \\
\text { assistants }\end{array}$ & $\begin{array}{l}\text { Significant } \\
\text { improvement in } \\
\text { mean scores } \\
\text { after training. }\end{array}$ \\
\hline
\end{tabular}

NR: Not reported

\section{Indirect outcomes}

Level 1. Two studies ${ }^{40,44}$ assessed participants' reaction to manikin-based simulation training. Specifically, Gilman et al. ${ }^{44}$ used a post-course satisfaction survey and found an overall satisfaction score of 4.39/5. No differences were found according to professions (i.e., nurses, doctors, respiratory therapists). Paige et al. ${ }^{40}$ assessed participants' reaction via open questions focusing on the value of simulation to learners and how to improve it after each training session. They found that participants generally felt that simulation training was worthwhile because it allowed to improve clinical skills, autonomy, and interprofessional collaboration.

Level 4. Capella et al. ${ }^{36}$ was the only study that assessed changes in organisational practice (Level 4a). They assessed the impact of manikin-based simulation training on the time to perform CT scans, endotracheal intubation, FAST-examination, as well as time to access the operating room and time spent in the emergency department. They found that most of these clinical indicators (i.e., time to CT scans, endotracheal intubation, and operating room) decreased significantly after the training, showing enhancement of trauma teams' ability to reach standard critical time indicators within their organization. 
Capella et al. ${ }^{36}$ was also the only study that assessed simulation training benefits for patients (Level 4b). They did not observe any change in complication rates, mortality rates, hospital length of stay, or intensive care unit length of stay before $(n=176)$ and after simulation training $(n=263)$.

\section{DISCUSSION}

This systematic review synthesized current evidence regarding the educational effectiveness of interprofessional manikin-based simulation training on teamwork in emergency trauma care. There was a significant heterogeneity across the 11 studies reviewed in terms of populations, interventions, and outcomes assessed. This limited our ability to pool the data using meta-analytical methods. All studies ranged from low to moderate methodological quality, which limits the generalizability of the review results. Still, our narrative synthesis suggests that interprofessional manikin-based simulation training is effective to improve teamwork perception/attitude, skills and behaviors of real teams during trauma resuscitation in adult emergency department immediately after training in various environments (i.e., laboratory, on-site, or in situ). Moreover, there is some evidence suggesting that interprofessional manikin-based simulation training could promote changes in organisational practice through enhanced adherence to critical time indicators (e.g., time to $\mathrm{CT}$, time to operating room). For retention of skills and behaviors, results showed divergent conclusions: some studies found lasting effects of training (3 weeks and 6 months post training $)^{38,41}$, while others found that training effects declined over time ( 4 weeks and 12 months post training) ) $^{38,39}$. Given these contradictory results, it is obvious that there is limited evidence about skills retention after the implementation of interprofessional manikinbased simulation training and that studies using a longitudinal design remain necessary.

Although this review used more specific inclusion criteria, our results are very similar to those of Gjeraa et al. ${ }^{17}$ and Barleycorn et al. ${ }^{16}$ - even though only three ${ }^{36,39,42}$ of the 11 studies analyzed in those prior reviews were included in our own. Since Gjeraa et al. ${ }^{17}$ and Barleycorn et al. ${ }^{16}$ considered studies with pseudo-teams, students, and less than three disciplines, as well as simulators with varying levels of fidelity (i.e., low to high), our results raise questions regarding the importance of certain simulation design characteristics related to fidelity for teamwork training.

It is generally acknowledged that higher fidelity is more effective for higher order learning outcomes, such as teamwork and other non-technical skills, and that lower fidelity is appropriate for knowledge or technical skills training. However, these ideas have been the subject of many debates, with some studies suggesting that fidelity influences simulation-based learning to a certain 
extent $^{19}$, while others showed that it does not ${ }^{59}$. These debates might be related to the various conceptualizations of fidelity. For example, Tun et al. ${ }^{12}$ recently proposed that fidelity consists of three dimensions: (1) the resemblance of the simulator or actor to an actual patient; (2) the resemblance of the environment to the clinical setting; and (3) the realism of the clinical scenario. In addition, Sharma et al. ${ }^{60}$ added the concept of sociological fidelity, which is concerned with the reproduction of the social factors, including professional boundaries, roles, power, etc.

When considering simulator fidelity, results about its influence on teamwork learning outcomes are scarce. Recent studies comparing low- and high-fidelity simulators to improve teamwork in nursing and medical students showed no superior educational benefits from either type of simulator ${ }^{61,62}$. Along with this reviews' results, these findings seem to support Norman et al.'s ${ }^{63}$ observation that the relationship between simulation fidelity and learning is not unidimensional and linear. It also suggests that simulators with any level of fidelity can provide improvements in teamwork-related outcomes and that there might be other dimensions of fidelity to consider.

This leads to wonder if sociological and environmental dimensions of fidelity — such as a simulation involving participants who work together in an actual team and deployed in a real clinical setting-would be more critical determinants of teamwork learning for healthcare professionals. Evidence suggests that the lack of a real social group participating in a simulation often detracts the ability of learners to believe in a situation ${ }^{64}$. With respect to environmental fidelity, most studies included in this review examined simulations in real clinical environments (in situ or on-site simulations), possibly because using the real work setting of participants has been suggested to be particularly valuable to enhance environmental fidelity and promote transfer of learning ${ }^{65}$. Nevertheless, results of this review suggest that in situ simulations would be just as effective as laboratory simulations to improve teamwork. In fact, there is currently no evidence to support the superiority of in situ simulations to enhance teamwork ${ }^{66}$. There is, however, some evidence suggesting that its effectiveness relies on the identification of patient security latent threats present in the care unit ${ }^{66}$.

\section{Recommendations for future research}

Similarly to previous reviews by Gjeraa et al. ${ }^{17}$ and Barleycorn et al. ${ }^{16}$, all studies included in the current review used a single-group, pretest-posttest design and none involved a control group. Considering that several health professional education experts agree that any 
educational intervention will lead to some sort of learning benefit when compared to no intervention ${ }^{67}$, controlled studies remain necessary to determine the specific effects of interprofessional manikin-based simulation training. Moreover, such studies could be quite beneficial in establishing the impact of specific simulator design characteristics. Consequently, to delineate the true contribution of simulation in trauma care, studies should rather focus on the features (e.g., fidelity, participants, environment, frequency, duration, content, debriefing) that make a simulation intervention more effective than another in a given context ${ }^{67,68}$.

Another important point is that most studies did not report a clear conceptual or operational definition of 'teamwork', with the exception of Gardner et al. ${ }^{37}$ who studied a precise concept related to team knowledge, 'transactive memory'. This absence of definition could be problematic for the advancement of knowledge in the field of trauma simulation as it may give the false impression that the concept of teamwork is simple and easily understood. As it was recently highlighted, teamwork is a concept used interchangeably with other related concepts such as NTS ${ }^{69}$ and CRM skills ${ }^{70}$. Moreover, no study mentioned a learning theory or theoretical perspective to support the study design even if it is recommended in simulations' standards of best practice ${ }^{71}$. Theories help to clarify an investigator's underlying assumptions and to sharpen the focus of the design, consequently strengthening the evaluation process. For these reasons, it would be important to clearly define teamwork based on conceptual or theoretical frameworks in future studies assessing this concept.

Regarding the tools used to assess teamwork, it should be noted that only two tools specific to teamwork evaluation in trauma care were used: T-TPOT ${ }^{57}$ and T-NOTECHS ${ }^{56}$. We also noted that some authors decided to use other scales not specifically designed to assess teamwork in trauma care, such as the Clinical Teamwork Scale $(\mathrm{CTS})^{58}$, a tool that was previously validated in obstetric teams. This suggest two things: (1) current tools may not meet researchers' needs; and (2) there might be a lack of awareness about the importance of using tools previously validated in the context in which the phenomenon under study occurs. Consequently, measurement tools rigorously created to assess trauma teamwork needs to be validated in this specific critical context $^{72}$.

As mentioned by Gjerra et al. ${ }^{17}$ and Barleycorn et al. ${ }^{16}$, a major challenge we encountered when conducting this systematic review was the heterogeneity of interventions ${ }^{73}$, which made it difficult to compare interventions, analyze results, and formulate clear and specific educational 
recommendations. This was partly due to incomplete and sometimes unclear reporting of the interventions under study. In 2016, extensions to the CONSORT guidelines for reporting healthcare simulation research were published and clearly state that the quality of reporting in educational intervention research is inconsistent and sometimes poor ${ }^{35}$. Based on these guidelines, we noticed that most studies included in the current review did not report basic elements, such as participants' orientation to simulator/environment, debriefing components, and integration to the educational curriculum, which are all key elements of simulation according to best practice standards ${ }^{71,74}$. In any case, future research should use these guidelines to guide their reporting.

Finally, it seems that the majority of the simulation literature has been limited to level 1 and level 2 outcomes, such as teamwork perception and acquisition of knowledge and skills. Although we recognize that monitoring changes in behaviors/practice is not an easy endeavor, not achieving this level of measurement leaves the studies open to the criticism that learners may have been taught to perform well only in a simulated environment and not in real life. Consequently, future research should focus on behavioral, organizational, and patient outcomes of simulationbased training.

\section{Limitations and strengths}

This systematic review is not without its limitations. First, studies relevant to the topic may have been excluded or missed as the literature search was based on a pre-defined search strategy, restricted to English and French languages. Since we decided to focus only on adult trauma emergency services, possibly relevant articles in the context of pediatric traumatology have not been considered. Also, as we did not search unpublished studies, there might be a risk of publication bias. However, by trying to address limitations of previous systematic reviews, we believe this review contributes further evidence regarding current knowledge on the effects of manikin-based simulation training on teamwork knowledge, skills and behavior in the adult emergency trauma care context.

\section{CONCLUSION}

Based on the literature reviewed, interprofessional manikin-based simulation training seems effective to improve teamwork perception/attitude, knowledge or skills, and behavior during trauma resuscitation in adult emergency departments immediately after training. In addition, there is some evidence that such training can lead to improvement in clinical trauma practice. For skills

and behaviors retention, conflicting results support the need for additional longitudinal studies. All 
studies found in this systematic review ranged from low to moderate methodological quality, mostly because they used a pre-post intervention design without any control group. While we utilized more specific inclusion criteria in order to better address the effects of interprofessional manikin-based simulations on actual trauma teams, our results are very similar to those of Gjeraa et al. ${ }^{17}$ and Barleycorn et al. ${ }^{16}$. This raises questions regarding the importance of simulation design characteristics. For these reasons, more extensive controlled trials of high quality are needed to show the real value of manikin-based simulations. Moreover, researchers should focus on comparing features of simulation intervention to really understand what works to enhance teamwork within interprofessional trauma care teams. 


\section{References}

1. Klein G, Feltovich PJ, Bradshaw J, Woods D. Common ground and coordination in joint activity. In: Rouse WB, Boff KR, eds. Organizational Simulation. Hoboken, New Jersey: Wiley-Interscience, pp. 139-184, 2005.

2. Vincent C, Amalberti R. Safety Strategies in Hospitals. Safer Healthcare: Strategies for the Real World. Cham: Springer International Publishing, pp. 73-91, 2016.

3. Georgiou A, Lockey DJ. The performance and assessment of hospital trauma teams. Scand J Trauma Resusc Emerg Med. 2010; 18: 66.

4. Barach P, B Weinger M. Trauma team performance. In: Wilson WC, Christopher M. Grande, Hoyt DB, eds. Trauma : Emergency Resuscitation, Perioperative Anesthesia, Surgical Management. Vol. 1: CRC Press, 2007.

5. Ivatury RR, Guilford K, Malhotra AK, Duane T, Aboutanos M, Martin N. Patient safety in trauma: maximal impact management errors at a level I trauma center. J Trauma. 2008; 64(2): 265-70; discussion 270-2.

6. Lubbert PH, Kaasschieter EG, Hoorntje LE, Leenen LP. Video registration of trauma team performance in the emergency department: the results of a 2-year analysis in a Level 1 trauma center. J Trauma. 2009; 67(6): 1412-20.

7. Schull MJ, Ferris LE, Tu JV, Hux JE, Redelmeier DA. Problems for clinical judgement: 3. Thinking clearly in an emergency. $\mathrm{CMAJ}:$ Canadian Medical Association journal = journal de l'Association medicale canadienne. 2001; 164(8): 1170-1175.

8. Larson JJ. In Search of Synergy in Small Group Performance. . New York, NY: Psychology Press, 2010.

9. Weaver SJ, Dy SM, Rosen MA. Team-training in healthcare: a narrative synthesis of the literature. BMJ Quality \&amp;amp; Safety. 2014; 23(5): 359.

10. Lopreiato JO. Healthcare Simulation Dictionary. Rockville, MD: Agency for Healthcare Research and Quality (AHRQ), 2016 ; Retrieved from.

11. Weaver SJ, Salas E, Lyons R, Lazzara EH, Rosen MA, Diazgranados D, Grim JG, Augenstein JS, Birnbach DJ, King H. Simulation-based team training at the sharp end: A qualitative study of simulation-based team training design, implementation, and evaluation in healthcare. J Emerg Trauma Shock. 2010; 3(4): 369-77.

12. Tun JK, Alinier G, Tang J, Kneebone RL. Redefining Simulation Fidelity for Healthcare Education. Simul Gaming. 2015; 46(2): 159-174.

13. Decker S, Sportsman S, Puetz L, Billings L. The evolution of simulation and its contribution to competency. J Contin Educ Nurs. 2008; 39(2): 74-80. 
14. Rosen MA, Salas E, Wu TS, Silvestri S, Lazzara EH, Lyons R, Weaver SJ, King HB. Promoting Teamwork: An Event-based Approach to Simulation-based Teamwork Training for Emergency Medicine Residents. Acad Emerg Med. 2008; 15(11): 11901198.

15. Østergaard D, Dieckmann P, Lippert A. Simulation and CRM. Best Pract Res Clin Anaesthesiol. 2011; 25(2): 239-249.

16. Barleycorn D, Lee GA. How effective is trauma simulation as an educational process for healthcare providers within the trauma networks? A systematic review. Int Emerg Nurs. 2018; 40: 37-45.

17. Gjeraa K, Møller T, Østergaard D. Efficacy of simulation-based trauma team training of non-technical skills. A systematic review. Acta Anaesthesiol Scand. 2014; 58(7): 775-87.

18. Lapierre A, Arbour C, Gauvin-Lepage J, Arbour C. Letter to the editor about "How effective is trauma simulation as an educational process for healthcare providers within the trauma networks? A systematic review". Int Emerg Nurs. 2019; : .

19. Kim J, Park J-H, Shin S. Effectiveness of simulation-based nursing education depending on fidelity: a meta-analysis. BMC Med Educ. 2016; 16: 152-152.

20. Dieckmann P, Gaba D, Rall M. Deepening the Theoretical Foundations of Patient Simulation as Social Practice. Simul Healthc. 2007; 2(3): 183-193.

21. Tufanaru C, Munn, Z., Aromataris, E., Campbell, J., Hopp, L. Chapter 3: Systematic reviews of effectiveness. Aromataris E, Munn, Z., ed. Joanna Briggs Institute Reviewer's Manual: The Joanna Briggs Institute, 2017 ; Retrieved from https://reviewersmanual.joannabriggs.org/

22. Moher D, Liberati A, Tetzlaff J, Altman DG. Preferred reporting items for systematic reviews and meta-analyses: the PRISMA statement. Ann Intern Med. 2009; 151(4): 264269.

23. Salas E. Team Training Essentials : A Research-Based Guide. London, UK: Routledge, 2015.

24. Engels PT, Paton-Gay JD, Tien HC. Trauma Team Structure and Organization. In: Gillman LM, Widder S, Blaivas Md M, Karakitsos D, eds. Trauma Team Dynamics: A Trauma Crisis Resource Management Manual. Cham: Springer International Publishing, pp. 47-54, 2016.

25. Barr H, Freeth, D., Hammick, M., Koppel, I., Reeves, S. Evaluations of interprofessional education: A United Kingdom review of health and social care. London, UK: CAIPE and the British Educational Research Association, 2000 ; Retrieved from.

26. Reeves S, Boet S, Zierler B, Kitto S. Interprofessional Education and Practice Guide No. 3: Evaluating Interprofessional Education. J Interprof Care. 2015; In Press. 
27. Blue AV, Chesluk BJ, Conforti LN, Holmboe ES. Assessment and evaluation in interprofessional education: exploring the field. J Allied Health. 2015; 44(2): 73-82.

28. Salas E, Rosen M, Shawn BC, Goodwin GF. The wisdom of collectives in organizations: An update of the teamwork competencies. . In: Salas E, Goodwin GF, Burke SC, eds. Team Effectiveness in Complex Organizations: Cross-Disciplinary Perspectives and Approaches. New York, NewYork: Routledge, pp. 39-79, 2009.

29. Salas E, Rosen, M., Shawn Burke, C., \& Goodwin, G. F. The wisdom of collectives in organizations: An update of the teamwork competencies. . In: Salas E, Goodwin, G.F., Burke, S. C., ed. Team Effectiveness in Complex Organizations: Cross-Disciplinary Perspectives and Approaches. New York, NewYork: Routledge, pp. 39-79, 2008.

30. Cooke N, Kiekel P, Salas E, Bowers C, Cannon-Bowers J. Measuring Team Knowledge: A Window to the Cognitive Underpinnings of Team Performance. Group Dynamicstheory Research and Practice - GROUP DYN-THEORY RES PRACT. 2003; 7.

31. Marshall SD, Flanagan B. Simulation-based education for building clinical teams. J Emerg Trauma Shock. 2010; 3(4): 360-8.

32. Savoldelli GL, Brindley PG, Jaffrelot M, Cardinal P. Chapter 25 - Crisis Resource Management and Nontechnical Skills: From Individuals to Teams, From Danger to Safety. In: Chiniara G, ed. Clinical Simulation (Second Edition): Academic Press, pp. 347-372, 2019.

33. Roberts F, Cooper K. Effectiveness of high fidelity simulation versus low fidelity simulation on practical/clinical skill development in pre-registration physiotherapy students: a systematic review. JBI Database System Rev Implement Rep. 2019; 17(6): 1229-1255.

34. The Cochrane Collaboration. Data extractions forms, 2019 ; Retrieved from https://dplp.cochrane.org/data-extraction-forms.

35. Cheng A, Kessler D, Mackinnon R, Chang TP, Nadkarni VM, Hunt EA, Duval-Arnould J, Lin Y, Cook DA, Pusic M, Hui J, Moher D, Egger M, Auerbach M, for the International Network for Simulation-based Pediatric Innovation R, Education Reporting Guidelines I. Reporting guidelines for health care simulation research: extensions to the CONSORT and STROBE statements. Adv Simul. 2016; 1(1): 25.

36. Capella J, Smith S, Philp A, Putnam T, Gilbert C, Fry W, Harvey E, Wright A, Henderson $\mathrm{K}$, Baker D, Ranson S, Remine S. Teamwork training improves the clinical care of trauma patients. J Surg Educ. 2010; 67(6): 439-43.

37. Gardner AK, Ahmed RA. Transforming Trauma Teams Through Transactive Memory:Can Simulation Enhance Performance? Simul Gaming. 2014; 45(3): 356-370. 
38. Harvey EM, Freeman D, Wright A, Bath J, Peters VK, Meadows G, Hamill ME, Flinchum M, Shaver KH, Collier BR. Impact of Advanced Nurse Teamwork Training on Trauma Team Performance. Clin Simul Nurs. 2019; 30: 7-15.

39. Miller D, Crandall C, Washington C, 3rd, McLaughlin S. Improving teamwork and communication in trauma care through in situ simulations. Acad Emerg Med. 2012; 19(5): 608-12.

40. Paige J, Garbee D, Yu Q, Kiselov V, Rusnak V, Detiege P. Moving Along: Team Training for Emergency Room Trauma Transfers (T(2)ERT(2)). J Surg Educ. 2019; 76(5): 1402-1412.

41. Roberts NK, Williams RG, Schwind CJ, Sutyak JA, McDowell C, Griffen D, Wall J, Sanfey H, Chestnut A, Meier AH, Wohltmann C, Clark TR, Wetter N. The impact of brief team communication, leadership and team behavior training on ad hoc team performance in trauma care settings. Am J Surg. 2014; 207(2): 170-8.

42. Steinemann S, Berg B, Skinner A, DiTulio A, Anzelon K, Terada K, Oliver C, Ho HC, Speck C. In situ, multidisciplinary, simulation-based teamwork training improves early trauma care. J Surg Educ. 2011; 68(6): 472-7.

43. Ziesmann MT, Widder S, Park J, Kortbeek JB, Brindley P, Hameed M, Paton-Gay JD, Engels PT, Hicks C, Fata P, Ball CG, Gillman LM. S.T.A.R.T.T.: development of a national, multidisciplinary trauma crisis resource management curriculum-results from the pilot course. J Trauma Acute Care Surg. 2013; 75(5): 753-8.

44. Gillman LM, Brindley P, Paton-Gay JD, Engels PT, Park J, Vergis A, Widder S. Simulated Trauma and Resuscitation Team Training course-evolution of a multidisciplinary trauma crisis resource management simulation course. Am J Surg. 2016; 212(1): 188-193.e3.

45. Amiel I, Simon D, Merin O, Ziv A. Mobile in Situ Simulation as a Tool for Evaluation and Improvement of Trauma Treatment in the Emergency Department. J Surg Educ. 2016; 73(1): 121-8.

46. Rosqvist E, Lauritsalo S, Paloneva J. Short 2-H in Situ Trauma Team Simulation Training Effectively Improves Non-Technical Skills of Hospital Trauma Teams. Scand J Surg. 2019; 108(2): 117-123.

47. Posner GD, Clark ML, Grant VJ. Simulation in the clinical setting: towards a standard lexicon. Adv Simul. 2017; 2(1): 15.

48. Mort TC, Donahue SP. Debriefing the basics. In: Dunn WF, ed. Simulators in critical care and beyond. Des Plains, IL: Society of Critical Care Medicine, 2004.

49. Klair MB. The mediated debrief of problem flights. . In: R. K. Dismukes, Smith GM, eds. Facilitation and debriefing in aviation training and operations Burlington, VT: Ashgate Publishing, pp. 72-92, 2000. 
50. Zangaro GA. Importance of Reporting Psychometric Properties of Instruments Used in Nursing Research. West J Nurs Res; 0(0): 0193945919866827.

51. King HB, Battles J, Baker DP, Alonso A, Salas E, Webster J, Toomey L, Salisbury M.

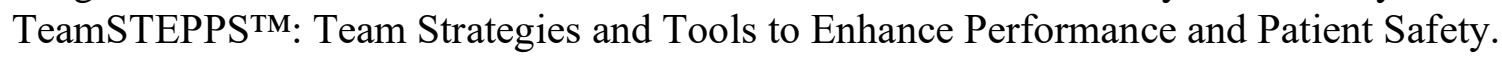
In: Henriksen K, Battles JB, Keyesl MA, et al., eds. Advances in Patient Safety: New Directions and Alternative Approaches (Vol. 3: Performance and Tools). Rockville (MD): Agency for Healthcare Research and Quality (US), 2008.

52. Castner J. Validity and reliability of the Brief TeamSTEPPS Teamwork Perceptions Questionnaire. J Nurs Meas. 2012; 20(3): 186-98.

53. Garbee DD, Paige J, Barrier K, Kozmenko V, Kozmenko L, Zamjahn J, Bonanno L, Cefalu J. Interprofessional Teamwork Among Students in Simulated Codes: A QuasiExperimental Study. Nurs Educ Perspect. 2013; 34(5): 339-344.

54. Parsell G, Bligh J. The development of a questionnaire to assess the readiness of health care students for interprofessional learning (RIPLS). Med Educ. 1999; 33(2): 95-100.

55. Kim J, Neilipovitz D, Cardinal P, Chiu M, Clinch J. A pilot study using high-fidelity simulation to formally evaluate performance in the resuscitation of critically ill patients: The University of Ottawa Critical Care Medicine, High-Fidelity Simulation, and Crisis Resource Management I Study. Crit Care Med. 2006; 34(8): 2167-2174.

56. Steinemann S, Berg B, DiTullio A, Skinner A, Terada K, Anzelon K, Ho HC. Assessing teamwork in the trauma bay: introduction of a modified "NOTECHS" scale for trauma. Am J Surg. 2012; 203(1): 69-75.

57. Baker D, Capella J, Hawkes C, Gallo J, Clinic C. The development of the Trauma Team Performance Observation Tool (TPOT). Communication presented at Annual meeting of the Society for Industrial and Organizational Psychology, Chicago, Illinois, 2011.

58. Guise JM, Deering SH, Kanki BG, Osterweil P, Li H, Mori M, Lowe NK. Validation of a tool to measure and promote clinical teamwork. Simul Healthc. 2008; 3(4): 217-23.

59. Massoth C, Röder H, Ohlenburg H, Hessler M, Zarbock A, Pöpping DM, Wenk M. Highfidelity is not superior to low-fidelity simulation but leads to overconfidence in medical students. BMC Med Educ. 2019; 19(1): 29.

60. Sharma S, Boet S, Kitto S, Reeves S. Interprofessional simulated learning: the need for 'sociological fidelity'. J Interprof Care. 2011; 25(2): 81-83.

61. Curran V, Fleet L, White S, Bessell C, Deshpandey A, Drover A, Hayward M, Valcour J. A randomized controlled study of manikin simulator fidelity on neonatal resuscitation program learning outcomes. Adv Health Sci Educ. 2015; 20(1): 205-218.

62. Hobgood C, Sherwood G, Frush K, Hollar D, Maynard L, Foster B, Sawning S, Woodyard D, Durham C, Wright M, Taekman J. Teamwork training with nursing and 
medical students: does the method matter? Results of an interinstitutional, interdisciplinary collaboration. Qual Saf Health Care. 2010; 19(6): e25.

63. Norman G, Dore K, Grierson L. The minimal relationship between simulation fidelity and transfer of learning. Med Educ. 2012; 46(7): 636-47.

64. Thomas L, Reeves S. Sociological fidelity: keeping the patient at the heart of interprofessional learning. J Interprof Care. 2015; 29(3): 177-8.

65. Hamstra SJ, Brydges R, Hatala R, Zendejas B, Cook DA. Reconsidering fidelity in simulation-based training. Academic medicine : journal of the Association of American Medical Colleges. 2014; 89(3): 387-92.

66. Sørensen JL, van der Vleuten C, Rosthøj S, Østergaard D, LeBlanc V, Johansen M, Ekelund K, Starkopf L, Lindschou J, Gluud C, Weikop P, Ottesen B. Simulation-based multiprofessional obstetric anaesthesia training conducted in situ versus off-site leads to similar individual and team outcomes: a randomised educational trial. BMJ Open. 2015; 5(10): e008344.

67. Cook DA. One Drop at a Time: Research to Advance the Science of Simulation. Simul Healthc. 2010; 5(1): 1-4.

68. Cook DA, Hamstra SJ, Brydges R, Zendejas B, Szostek JH, Wang AT, Erwin PJ, Hatala R. Comparative effectiveness of instructional design features in simulation-based education: systematic review and meta-analysis. Med Teach. 2013; 35(1): e867-98.

69. Gordon M, Darbyshire D, Baker P. Non-technical skills training to enhance patient safety: a systematic review. Med Educ. 2012; 46(11): 1042-54.

70. Gillman LM, Widder S, Blaivas M, Karakitsos D. Trauma Team Dynamics: A Trauma Crisis Resource Management Manual: Springer International Publishing, 2015.

71. INACSL Standards Committee. INACSL Standards of Best Practice: Simulation Design. Clin Simul Nurs. 2016; 12: S5-S12.

72. Boet S, Etherington N, Larrigan S, Yin L, Khan H, Sullivan K, Jung JJ, Grantcharov TP. Measuring the teamwork performance of teams in crisis situations: a systematic review of assessment tools and their measurement properties. BMJ Qual Saf. 2019; 28(4): 327.

73. Reed D, Price EG, Windish DM, Wright SM, Gozu A, Hsu EB, Beach MC, Kern D, Bass EB. Challenges in Systematic Reviews of Educational Intervention Studies. Ann Intern Med. 2005; 142 (12 (2)): 1080-1089.

74. Motola I, Devine LA, Chung HS, Sullivan JE, Issenberg SB. Simulation in healthcare education: a best evidence practical guide. AMEE Guide No. 82. Med Teach. 2013; 35(10): e1511-30. 


\section{List of Supplemental Digital Content (SDC)}

Supplemental Digital Content 1. doc, Table - Summary of the studies and simulation characteristics 